\title{
Editorial
}

The second issue of the Bulletin (which, regretfully, appears a little behind schedule) follows largely the pattern of the first. The only innovations are a section devoted to bibliography and a section of short book notes. The bibliography of G.R.G. Mure's philosophical writings completes the two articles on him published in the Spring/Summer 1980 issue of the Bulletin. The Editor would welcome short notes (up to 200 words) on recent books which, though they deal primarily with other subjects, have important chapters or sections relevant to Hegel.

The second issue, however, has a more international flavour than the first. It contains reviews of a number of books published on the continent of Europe, and a bibliography of books and articles on Hegel published in Italy in 1978 and 1979. It is hoped that similar national bibliographies will appear in future issues of the Bulletin and they may be complemented by survey-articles outlining major trends in Hegelian scholarship in various countries since 1945. The Editor believes that English-speaking students of Hegel will want to know of recent publications in foreign languages and hopes the information may also be of interest to English-language publishers.

The Editor is very grateful to Professor W.H. Walsh and Professors C. Cesa and G. Marini for their bibliographies, and to $\mathrm{Dr}$. U. Rameil for his article on the Hegel Archive.

\section{Announcements and Reports}

\section{Second Conference of the Hegel Society of Great Britain}

The second annual conference of the HSGB took place at Pembroke College, Oxford on 22-23 September 1980. Papers were read by Dr. Z.A. Pelczynski (Pembroke College), Prof. R. Plant (University of Southampton), Mr. S. Bungay (St. Catherine's College, Oxford), Dr. B. Parekh (University of Hul1) and Prof. A.R. Manser (University of Southampton). Thirty-six members attended the conference.

Dr. Pelczynski opened the conference with a review of the life and Hegelian scholarship of T.M. Knox. (His paper appears elsewhere $\mathrm{j} n$ this Bulletin). An exhibitjon of Knox's writings, papers, letter's and photographs was held in the College library 
during the conference. It ronsisted of 96 items and provided a kind of visual supplement to Dr. Pelrzynski's paper.

The conference resumed in the evening with a short business meeting which heard reports from the Chairman, Secretary/ Treasurer and the Editor of the Bulletin. The meeting recorded its gratitude to Merton college for its generous grant towards the publication of the first issue of the Eulletin. It was announced that subscriptions to the society would remain at. $\$ 3$ per annum. Conference was also informed of relations with overseas societies and a committee, consisting of the Society's officers and Professors W.H. Walsh and L. Pompa, was delegated with the responsibility for organizing a joint conference with the Hegel Society of America in 1981. Conference then adopted the rules of the society and re-elected the officers and members of the Council.

Professor Plant in his paper 'Identity and Legitimacy in Hegel', took as his starting-point Habermas's Leqitimation Crisis which, he argued, dealt with the issue of the relationship between state and economy raised in Hegel's work. For Habermas the crisis of legitimation arises from the dysfunctional effects of the market, for Hegel the problem is one of identity: how can individuals, immersed in particularity, identify with the state? For both, modern economic $\mathrm{l}$ ife is characterised by a highly individualistic system of needs which atomises the members of society and which represents a loss of morality. The pure economic market is unhealthy for individuals who experience deprivation and alienation, but is also unhealthy for society as a whole, which lacks strong links between individuals. Given this, how can the economic sphere forge links with moral and ethical life? One solution lies in the strong state. But while Hegel sees the value of the state in controlling the market and thereby mitigating poverty, any attempt on the part of the state to impose moral norms from the outside would be inevitably authoritarian and hence unacceptable. - Gemeinschaft for Hegel must arise internally through the attitudes of members of society and developed within their system of needs through labour. Plant concluded that although Hegel provides a perceptive analysis of the problems facing the modern state and correctly identifies the need for a sense.of involvement or community, he fails to show how this transforma$t i o n$ in economic life is likely to be achieved, how this sense of community energes or what kind of civil society is necessary for such a development. The evening wound to a close with a Iively discussion of the problems posed by Professor Plant's paper.

The morning session opened with a paper by Stephen Bungay entitled 'Hegel and the Problem of Metaphysics'. Twentiethrentury philosophers have, on the whole, united in the face of the bogey of Hegelian metaphysics: linguistic philosophers, logical positivists, wittgenstejnians and dialectical materialists have all seen metaphysics as an impediment to philosophical inquiry. Indeed Bungay opened his paper with the remark that if a student of philosophy wondered what metaphysics was, he might be forgiven for thinking that it was a name for bad philosophy. However, the reply to Hegel's critics is usually found in the master's texts. Quoting liberally from the 
Science of Logic and the Encyclopaedia, Bungay proceeded from the distinction between Kantian and Hegelian metaphysics to a comprehensive outline of the role of metaphysics in Hegel's project. According to Bungay, the salient feature of Hegel's concept of metaphysics is that 'he does not try to tell us what the essence of reality is', nor does he commit the classical metaphysical error of presupposing metaphysical principles by means of which other metaphysical systems can be dismantled. Instead he shows what it is to think determinately, 'to think about thinking about things'. On close analysis it seems that Hegel's thought has more in common with the progressive strands in modern conceptual analys is than with the atrophied systems of the early nineteenth century with which he is often associated. The following discussion centred on the status of religion in Hegel's work. A variety of interpretations of Hegel's claim that philosophy and religion have the same object of study were offered.

The morning session concluded with Dr. Parekh's paper on 'Marx's relation to Hegel'. Combining Hegel's with his own distinctive ideas, Marx produced a body of thought that was cast in a Hegelian mould but had a non-Hegelian content. In other words, while Marx is unintelligible without reference to Hege1, he was not a Hegelian or even a neo-Hegelian thinker. Parekh argued that Marx began by rejecting Hegel, but when he later turned his attention to the analysis of the nature and dynamics of capitalism, he began to appreciate Hegel's importance. His own epistemology implied that Hegel's philosophy was an articulation of his epoch and had in its own way offered a profound analysis of capitalism. Accordingly Marx. relied heavily on Hegel's ontology and dialectical logic. He understood capital along the lines of Hegel's Geist and related it to commodity broadly as Hegel had related the Geist to finite entities. Like the Geist, capital is inherently restless, self-propelling, self-expanding, universalistic and all-powerful.

Marx took over what he called the rational kernel of Hegel's dialectical method. 'This consisted in the view that an entity is self-contradictory when its telos is at odds with its conditions of existence. Un1ike Hegei, however, Marx defined the twin concepts of telos and the conditions of existence in materialistic terms. He deontologised and historicised the dialectic, redefined such crucial categories as opposition, contradiction, negation and supersession in materialist terms, and gave the dialectic the dimension of praxis it had lacked in Hegel.

Since Marx did not systematically criticise Hegel, he was not, Parekh argued, fully conscious of his relation to him. Not surprisingly, he took over far more from Hegel than was compatible with his historical materialism. Hegel's doctrine of the identity of the subject and the object is evident in his dubious equation of the human species and the productive forces. He also took over large parts of Hegel's philosophy of history (cf. the 'historical task' of capitalism, the historical necessity of class-conflict, the 'historical signif icance' of private property, and so on). Parekh concluded that Marx's thought contains several large chunks of undigested 
and indigestible Hegelianism. While Marx's historical investigations point away from Hegel, his theoretical selfconsciousness remained profoundly Hegelian (as is evident in the .2859 Preface and the Grundrisse).

The final paper, 'Teleology in llegel', given by Professor Manser, consisted of a detailed commentary on the chapter on teleology in Hegel's Science of Logic. Contrasting Hegel's account of teleology with earlier teleologies, which attributed purposive ends to nature, Manser argued that Hegel's teleology is primarily humanistic. Teleology was reintroduced into modern philosophy by Kant, and Hegel maintained that he had raised the right questions but given the wrong answers, Hegel's own account of purpose marks a radical departure from the tendency to present formal distinctions between final and efficient causes, mechanism and purpose. According to Manser, Hegel's concept of teleology is best approached through an analysis of human desire and skilled labour. In order to fujfil his desires and render the world hospitable, the craftsman or farmer is forced to interact with the external world, making use of tools and natural laws, and in so doing adding to his knowledge of nature and increasing the scope of future desires and possibilities. With references to the science of Logic and examples from the Philosophy of History, Manser illustrated Hegel's account of the 'cunning of man' who, in the employment of tools and machinery, such as ploughs and windmills, reveals that nature's mechanism and human finality are not externally opposed but are integral monents in a dialectical totality where ends and means are not distinct categories but are fluid and interpenetrable. In the following discussion the similarities and dissimilarities between the Hegelian and Darwinian conceptions of evolution were considered. The conference closed at 4 p.m.

\section{S. Easton}

University of Sussex

\section{Sixth Biennial Convention of the Hegel Society of America}

The sixth biennial meeting of the Hegel Society of America was held on 2-4 October 1980 in Champlain College, Trent university, peterborough, Ontario, in very scenic surroundings and against the colourful background of canadian autumn. Prof . John Burbidge (Trent) was in charge of local arrangements and Prof. K.R. Dove (Benington College), as programme Chairman, was responsible for the finalization of papers and speakers. The proceedings followed a formal pattern: a forty-minute lecture, a twenty-minute comment and a general discussion. A very full programme and a large number of participants produced a slightly rushed atmosphere during the convention, but one will get a second, more leisurely chance to digest the rich and varied intellectual fare when the proceedings of the convention in due course appear in print (there is hope it will be somewhat sooner than in the past). 